\title{
PENGEMBANGAN MODUL ELEKTRONIK FLIPBOOK BERBASIS PROBLEM BASED LEARNING PADA MATERI INDUKSI ELEKTRONIK SMA KELAS XII
}

\author{
Farah Muthi Hermawati $^{\text {a) }}$, Sunaryo ${ }^{\text {b) }}$, Cecep E. Rustana ${ }^{\text {c) }}$ \\ Program Studi Pendidikan Fisika, Fakultas Matematika dan Ilmu Pengetahuan Alam, Universitas Negeri \\ Jakarta, Jl. Rawamangung Muka No. 1, Rawamangun, Pulogadung, Jakarta Timur 13220, Indonesia \\ Email: ${ }^{\text {a)}}$ fmhermawati@ hotmail.com, ${ }^{\text {b) }}$ naryounj@yahoo.co.id, ${ }^{\mathrm{c})}$ ce.rustana59@gmail.com
}

\begin{abstract}
Abstrak
Pembelajaran fisika abad 21 memerlukan berbagai inovasi di bidang media pembelajaran. Salah satu inovasi yang dapat dilakukan adalah mengembangkan modul elektronik flipbook sebagai sebuah alternatif untuk mempelajari induksi elektromagnetik. Tujuan dari penelitian ini adalah untuk melakukan analisis awal dan mengembangkan flipbook pada induksi elektromagnetik berbasis PBL untuk siswa SMA kelas XII. Metode Dick and Carey pada Research and Development diadopsi untuk mengembangkan produk yang mencakup bagian cover, pendahuluan, isi dan penutup yang dilengkapi dengan soal-soal berbasis berpikir tingkat tinggi (HOTS). Validasi produk lebih lanjut akan dilakukan oleh ahli pembelajaran, media dan materi. Hasil penelitian awal dari pengembangan modul flipbook ini menunjukan bahwa modul tersebut sangat diperlukan dalam pembelajaran Fisika. Hal itu didasari pada pendapat siswa yang menyatakan bahwa $61 \%$ pembelajaran di sekolah belum efektif dalam hal penggunaan media berbasis teknologi kemudian $42 \%$ siswa menyatakan bahwa induksi elektromagnetik menjadi materi yang dianggap sulit oleh siswa. Selain itu, prototype produk flipbook telah berhasil dikembangkan dan akan dilakukan validasi lebih lanjut dan implementasi pada penelitian berikutnya. Kesimpulan dari penelitian ini adalah bahwa flipbook berbasis PBL sangat diperlukan dan berpotensi memiliki keunggulan untuk digunakan untuk pembelajaran fisika induksi elektromagnetik di SMA.
\end{abstract}

Kata-kata kunci: modul elektronik, flipbook, induksi elektromagnetik.

\begin{abstract}
21 st-century physics learning requires various innovations in the field of instructional media. One innovation that can be done is to develop a flipbook electronic module as an alternative to studying electromagnetic induction. The purpose of this study was to conduct preliminary analysis and develop a flipbook on PBL-based electromagnetic induction for high school students in class XII. Dick and Carey method in Research and Development was adopted to develop products that include the cover, introduction, content, and cover sections that are equipped with questions based on higher-order thinking (HOTS). Further product validation will be carried out by learning experts, media, and material. Initial research (preliminary analysis) results from the development of this flipbook module showed that the module was very necessary in Physics learning. This is based on the students' opinion which states that $61 \%$ of learning in schools is not yet effective in terms of the use of technology-based media. Then $42 \%$ of students state that electromagnetic induction is a learning material that is considered difficult by students. Besides, the prototype of the flipbook product has been successfully developed and further validation and implementation will be carried out in subsequent studies. This
\end{abstract}


research concluded that the PBL-based flipbook was very necessary and have the potential to be used for learning electromagnetic induction physics in high school.

Keywords: electronic modules, flipbooks, electromagnetic induction.

\section{PENDAHULUAN}

Pada pembelajaran fisika abad 21, media pembelajaran menjadi komponen penting dalam proses belajar mengajar. Berdasarkan penelitian yang dilakukan oleh Johnson dan Marburger menjelaskan bahwa media pembelajaran yang sedang berkembang pada pembelajaran fisika adalah media pembelajaran berbasis digital [1-2]. Hal ini dikarenakan terdapat banyak konsep yang dipelajari dalam pembelajaran fisika, dan media pembelajaran berbasis digital dapat memvisualisasikan konsep tersebut sehingga mudah dipelajari oleh siswa serta membantu guru dalam menjelaskan materi.

Media pembelajaran yang dapat digunakan diantaranya simulasi PhET [3-4], website to android app [5], Augmented Reality [6], dan e-learning [7]. Diantara beberapa media pembelajaran berbasis digital, modul elektronik dapat menjadi media pembelajaran digital yang cocok dalam pembelajaran fisika, karena beberapa fitur yang dapat disisipkan seperti, audio, video, gambar, dan animasi yang dapat membantu siswa dalam memahami materi [8]. Selain itu modul elektronik dinilai praktis karena dapat disajikan dalam berbagai perangkat seperti laptop, tablet, ataupun telepon pintar (smartphone) sehingga baik siswa ataupun guru dapat mengakses dimana saja, dan kapan saja [9].

Beberapa pengembang mengeluarkan beberapa jenis software modul elektronik flipbook, jika ditinjau dari berbagai fiturnya 3D PageFlip Professional [10] memiliki beberapa fitur yang cocok untuk dijadikan software pengembang media pembelajaran fisika seperti mendukung pemutar video, pemutar animasi (.swf atau .gif), dan dapat menyematkan hyperlink atau objek multimedia lainnya [11]. Dengan adanya beberapa fitur tersebut akan membantu guru dalam memvisualisasikan materi yang diajarkan. Beberapa materi fisika dinilai sulit dipelajari karena siswa tidak mampu memvisualisasikan konsep yang dijelaskan, diantaranya adalah induksi elektromagnetik [12]. Induksi elektromagnetik merupakan salah satu materi fisika yang mempelajari listrik dan magnet yang wajib dipahami oleh siswa. Materi induksi elektromagnetik dalam penerapannya berkaitan dengan sains dan teknologi yang relevan dengan kehidupan sehari-hari yang memerlukan kemampuan siswa dalam berpikir.

Berdasarkan berbagai penelitian terdahulu menyatakan bahwa rendahnya kemampuan berpikir tingkat tinggi atau Higher Order thinking Skills (HOTS) menjadi salah satu masalah dalam pembelajaran sains [13-14]. Hal tersebut menjadikan inovasi pembelajaran perlu dikembangkan sebagai upaya meningkatkan kualitas pembelajaran sains. Salah satu model yang bisa digunakan dalam pembelajaran sains adalah dengan menggunakan Problem based learning (PBL) [15-16]. Model ini merupakan salah satu yang dapat memfokuskan kemampuan siswa untuk memcahkan masalah. Hal ini sesuai dengan karakteristik materi induksi elektronik yang memerlukan kemampuan pemecahan masalah. Modul elektronik dalam hal ini flipbook bisa menjadi salah satu solusi untuk memcahkan masalah tersebut. Berdasarkan uraian tersebut maka penelitian ini menjadi urgen untuk dilakukan dikarenakan rendahnya kemampuan siswa dalam mengatasi berbagai masalah, khususnya terkait induksi elektromagnetik. Berdasarkan hal tersebut maka tujuan dari penelitian ini adalah untuk melakukan analisis awal dan mengembangkan modul flipbook pada materi induksi elektronik untuk siswa.

\section{METODOLOGI PENELITIAN}

Metode penelitian yang digunakan dalam penelitian ini adalah dengan metode penelitian dan pengembangan (Research and Development). Dengan model pengembangan Dick and Carey. Menurut Dick and Carey terdapat 10 langkah penelitian yaitu (1) Mengidentifikasi tujuan instruksional; (2) Melakukan analisis instruksional; (3) Mengidentifikasi karakteristik siswa dan konteks pembelajaran; (4) Merumuskan tujuan kinerja; (5) pengembangan instumen pembelajaran; (6) mengembangkan strategi instruksional; (7) Memilih dan mengembangkan bahan instruksi; (8) Merancang dan melaksanakan evaluasi formatif; (9) Revisi instruksi; dan (10) Mendesain dan 
melaksanakan evaluasi sumatif [17]. Seteelah data telah didapatkan maka data akan diolah dengan melakukan pengujian seperti uji normalitas, uji homogenitas, gain ternormalisasi, dan uji effect-size.

\section{HASIL DAN PEMBAHASAN}

Berdasarkan Langkah - Langkah metodologi penelitian Dick and Carey, maka hasil penelitian sesuai dengan prosedur penelitian dan pengembangan yang sudah dilakukan adalah sebagai berikut

\section{Mengidentifikasi tujuan instruksional}

Pada tahap ini mengidentifikasi tujuan pengembangan produk. Tujuan pengembangan produk dilatarbelakangi oleh penelitian dari Mardiansyah yang berpendapat bahwa penggunaan media pembelajaran berbasis digital dapat membangun pola pikir tingkat tinggi siswa dan berpikir kritis [18]. Selain itu, dilatarbelakangi penelitian dari Fitriyani yang berpendapat bahwa media elektronik dapat menjadi salah satu media pembelajaran yang dapat dikembangkan karena dilengkapi dengan fasilitas berbagai multimedia penunjang seperti audio, video, gambar, dan lainnya sehingga dapat terciptanya pembelajaran mandiri [11]. Terakhir, dilatarbelakangi oleh penelitian dari Sari yang berpendapat bahwa pembelajaran dengan modul elektronik lebih mudah, menarik, serta interaktif bagi siswa [19].

\section{Melakukan analisis intruksional}

Dalam langkah ini dilakukan analisis kebutuhan terkait dengan penelitian selanjutnya. Analisis kebutuhan dilakukan terhadap 38 siswa di daerah Jakarta dan Bekasi. Dengan analisis kebutuhan diketahui bahwa $61 \%$ pembelajaran di sekolah belum efektif menggunakan media pembelajaran pada saat proses belajar mengajar, dan sebesar $42 \%$ siswa menyatakan bahwa induksi elektromagnetik menjadi materi yang dianggap sulit oleh siswa.

\section{Mengidentifikasi perilaku dan karakteristik awal siswa}

Dalam pembelajaran, siswa dapat membutuhkan media yang dapat memvisualisasikan konsep materi yang dipelajari. Modul elektronik merupakan media yang cocok untuk memvisualisasikan konsep pada materi induksi elektromagnetik.

\section{Menulis Tujuan Kinerja}

Berdasarkan analisis yang dilakukan pada tahapan sebelumnya, maka pada tahapan ini dilakukan penulisan tujuan pembelajaran yang dirumuskan berdasarkan indikator pembelajaran untuk materi Induksi Elektromagnetik dalam KD 3.4 dan 4.4 kelas XII SMA: (3.4) Menganalisis fenomena induksi elektromagnetik dalam kehidupan sehari - hari; (4.4) Melakukan percobaan tentang induksi elektromagnetik berikut presentasi hasil percobaan dan pemanfaatannya dalam kehidupan sehari hari. Dengan tujuan pembelajaran pada KD 3.4 dan 4.4 adalah (a) Siswa dapat memahami peristiwa terjadinya gaya gerak listrik (GGL) induksi; (b) Siswa dapat memahami hukum Lenz; (c) Siswa dapat menganalisis percobaan Faraday; (d) Siswa dapat menganalisis cara kerja generator; dan (e) Siswa dapat menganalisis cara kerja transformator.

\section{Mengembangkan Instrument Acuan}

Dalam tahapan ini, instrument HOTS yang digunakan dalam penelitian ini adalah dengan menggunakan pretest dan posttest. Pretest dilaksanakan sebelum siswa belajar menggunakan modul elektronik pengembangan, sedangkan posttest dilaksanakan setelah siswa belajar menggunakan modul elektronik pengembangan. 


\section{Mengembangkan Strategi Instruksional}

Untuk menghasilkan modul elektronik pengembangan berbasis PBL, maka perlu rancangan langkah - langkah pembelajaran berdasarkan tahapan PBL untuk mengembangkan media pembelajaran dan menyusun konsep materi yang akan dipelajari. Mayanti menjelaskan terdapat 5 tahapan diantaranya (a) Tahap Permasalahan, dimana Siswa melakukan kegiatan pengamatan atau observasi serta mengemukakan hipotesis terkait dengan permasalahan yang terdapat pada pendahuluan (apersepsi); (b) Tahap Belajar, dimana Siswa melakukan proses pencarian jawaban dari pertanyaan yang berasal dari permasalahan pada pendahuluan (apersepsi) dengan dibantu oleh sumber belajar yang disajikan pada media pembelajaran pengembangan; (c) Tahap Penyelidikan, dimana Siswa melakukan penyelidikan sederhana yang berkaitan dengan permasalahan yang terdapat pada pendahuluan (apersepsi); (d) Tahap Pengembangan Hasil, dimana Siswa mengembangkan hasil data yang temukan dari tahap sebelumnya, dan disajikan dalam berupa uraian atau simulasi; dan (e) Tahap Analisis dan Evaluasi, dimana siswa menganalisis hasil data yang telah didapat, melakukan pembuktian hipotesis, dan melakukan evaluasi dari proses pemecahan masalah yang dilakukan [20].

\section{Mengembangkan dan Memilih Bahan Instruksional}

Bahan pembelajaran yang dibahas dalam modul elektronik penembangan adalah materi induksi elektromagnetik dengan 2 kegiatan belajar. Pada kegiatan belajar 1 terdiri dari 6 sub bab yaitu (a) percobaan Faraday; (b) Fluks Magnet; (c) Hukum Faraday; (d) Hukum Lenz; (e) induksi elektromagnetik pada kawat lurus; dan (f) induksi elektromagnetik pada kawat berputar. Pada kegiatan belajar II terdiri atas 2 sub bab yaitu (a) pengaplikasian generator; dan (b) pengaplikasian transformator. Tampilan produk modul flipbook secara lebih rinci dapat dilihat pada gambar 1 dan 2.

\section{Mendesain dan Melaksanakan Evaluasi Formatif}

Evaluasi formatif merupakan proses validasi produk modul pengembangan oleh para ahli (validator) dan responden. Para ahli yang akan menilai modul elektronik pengembangan ialah ahli materi, ahli media, dan ahli pembelajaran. Sedangkan responden terdiri dari guru dan siswa. Pada penelitian ini tahapan ini belum dilaksanakan.

\section{Merevisi Kegiatan Instruksional}

Melakukan revisi media pengembangan dilakukan untuk mengetahui kekurangan yang ditemukan pada modul elektronik pengembangan setelah dilakukan validasi. Revisi dilakukan berdasarkan data hasil evaluasi formatif atau uji coba kelas kecil. Pada penelitian ini tahapan ini belum dilaksanakan dan akan dilaksanakan pada penelitian selanjutnya.

\section{Mendesain dan Melaksanakan Evaluasi Summatif}

Evaluasi sumatif dilakukan setelah produk selesai dievaluasi secara formatif, dan direvisi berdasarkan data dari evaluasi formatif. Evaluasi sumatif yang dilakukan dengan menggunakan pretest dan posttest. Tahapan evaluasi ini belum dilaksanakan dan akan dilaksanakan pada penelitian selanjutnya. 


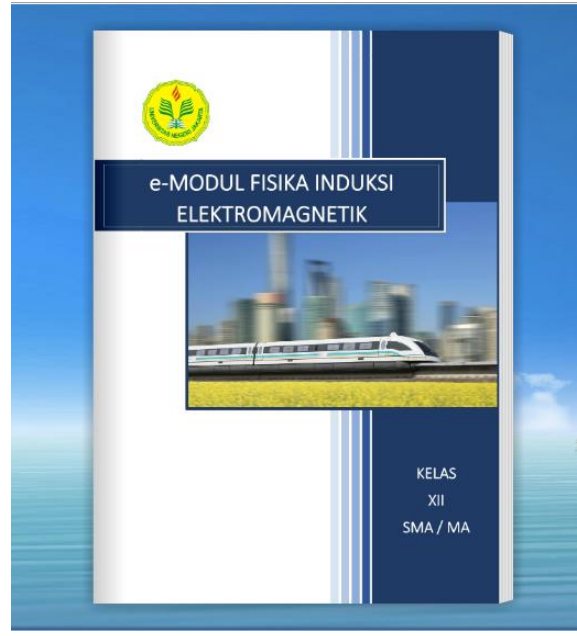

(a)

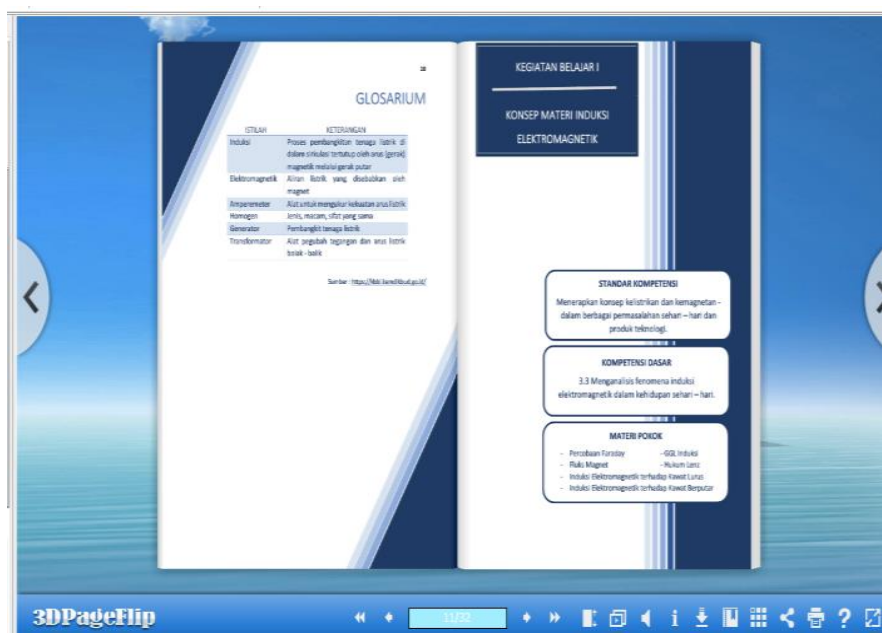

(b)

GAMBAR 1. Tampilan Awal Modul Elektronik (a); Tampilan Modul Elektronik pada bagian Glosarium dan Kegiatan Belajar I

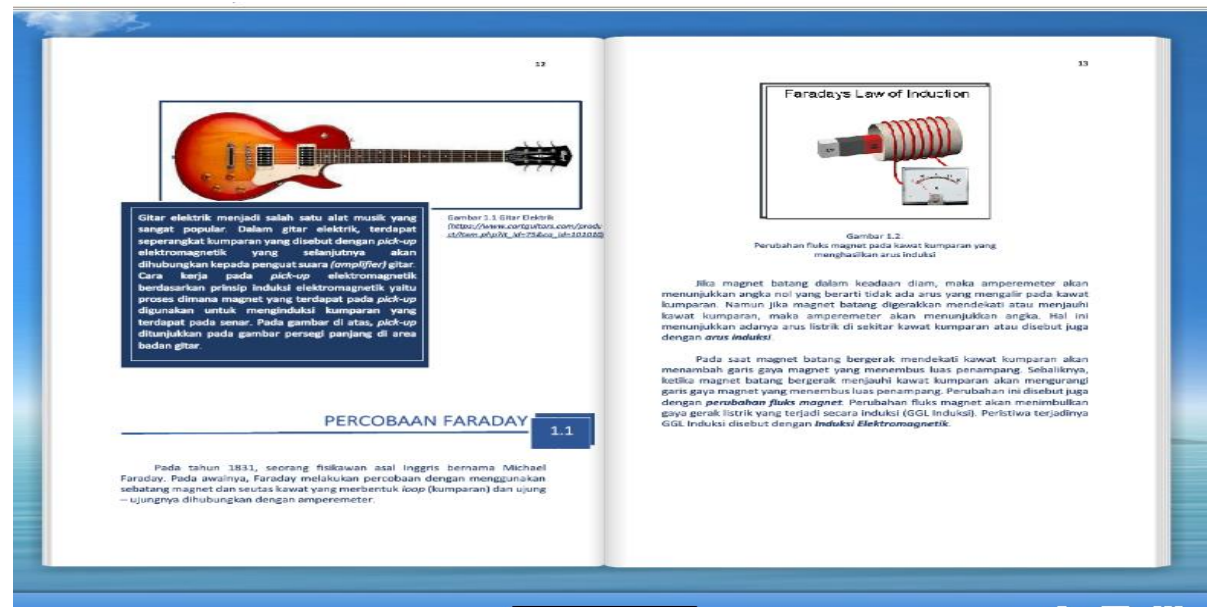

GAMBAR 2. Tampilan dari Modul Elektronik pada bagian Apersepsi (di sebelah kiri) dan animasi dari materi (di sebelah kanan)

Modul elektronik merupakan sebuah bentuk inovasi pembelajaran fisika di abad 21. Hal ini dikarenakan modul elektronik sesuai dengan perkembangan teknologi yang digunakan dalam pembelajaran. Pengembangan pembelajaran berbasis teknologi akan memudahkan siswa untuk bisa memahami berbagai konsep yang sulit dipahami. Minimnya waktu yang disediakan di kelas membuat pengembangan media pembelajaran berbasis teknologi menjadi sebuah kebutuhan. Salah satu yang dapat dikembangkan adalah media modul elektronik flipbook pada materi induksi elektromagnetik. Hadirnya modul ini merupakan salah satu bentuk upaya untuk mendukung pembelajaran secara digital. Inovasi pembelajaran berbasis teknologi menjadikan sebuah urgensi untuk mengembangkan pembelajaran agar meningkatkan kualitas pendidikan [21-23].

Pembelajaran secara digital sangat sesuai dengan keadaan yang dialami saat pandemik Coronavirus Diseases (COVID-19). Adanya wabah ini membuat pembelajaran tatap muka menjadi ditiadakan. Hal ini berdampak kepada perubahan strategi pembelajaran sains yang harus digunakan. Pembelajaran fisika disaat pandemik COVID-19 juga harus mengalami perubahan dari pertemuan tatap muka di kelas menjadi sistem daring (online). Perubahan strategi pembelajaran menjadi online ini tentu juga memerlukan sebuah media yang sesuai untuk digunakan dalam rangka mendukung 
pembelajaran sains abad 21 [24-25]. Salah satunya adalah dengan media modul elektronik yang dikembangkan dalam penelitian ini.

Modul flipbook ini memiliki keunggulan yaitu bisa digunakan secara jarak jauh. Siswa tidak perlu hadir ke kelas untuk menggunakan media modul flipbook ini. Siswa bisa mengakses modul flipbook ini dimanapun dan kapanpun tanpa harus hadir ke kelas. Hal ini tentu merupakan keunggulan dari modul flipbook ini sebagai sebuah media pembelajaran yang akan mendukung pembelajaran fisika secara jarak jauh disaat pandemik COVID-19. Selain itu, keunggulan lainnya dari media ini adalah bahwa siswa bisa mengakses berbagai materi tentang induksi dalam berbagai bentuk. Berbeda dengan modul cetak yang konvensional. Modul flipbook yang dikembangkan ini dapat menyajikan materi dalam bentuk animasi yang akan memudahkan siswa dalam memahami pembelajaran induksi. Hal ini menjadikan modul elektronik secara teknis lebih unggul dibandingkan dengan modul konvensional[26-27]

\section{SIMPULAN}

Media pembelajaran modul elektronik flipbook berbasis PBL ini dikembangkan dengan metode penelitian dan pengembangan (Research and Development) dengan model Dick and Carey. Dalam penyajiannya, modul elektronik ini dapat memvisualisasikan konsep - konsep pada materi Induksi Elektromagnetik dengan beberapa media diantaranya gambar, video, animasi ataupun multimedia pendukung lainnya. Hasil penelitian awal menunjukan bahwa modul elektronik ini sangat dibutuhkan oleh siswa dan juga prototype dari modul elektronik ini sudah berhasil dikembangkan.

\section{REFERENSI}

[1] J. Johnson et al., "The FuturICT education accelerator," Eur. Phys. J. Spec. Top., vol. 214, no. 1, pp. 215-243, Nov. 2012, doi: 10.1140/epjst/e2012-01693-0.

[2] J. H. Marburger, "Science, technology and innovation in a 21st century context," Policy Sci, vol. 44, no. 3, pp. 209-213, Sep. 2011, doi: 10.1007/s11077-011-9137-3.

[3] P. Sinulingga, T. J. Hartanto, and B. Santoso, "Implementasi Pembelajaran Fisika Berbantuan Media Simulasi PhET untuk Meningkatkan Hasil Belajar Siswa Pada Materi Listrik Dinamis", JPPPF (Jurnal Penelitian dan Pengembangan Pendidikan Fisika), vol. 2, no. 1, pp. 57 - 64, Jun. 2016.

[4] S. Siswoyo, "Development of Teacher Guidebook for Photoelectric Effects Instructional Using Predict-Observe-Explain Strategy with PhET Interactive Simulation", JPPPF (Jurnal Penelitian dan Pengembangan Pendidikan Fisika), vol. 5, no. 2, pp. 133 - 144, Nov. 2019.

[5] B. R. Simanjuntak, D. Desnita, and E. Budi, "The Development of Web-based Instructional Media for Teaching Wave Physics on Android Mobile", JPPPF (Jurnal Penelitian dan Pengembangan Pendidikan Fisika), vol. 4, no. 1, pp. 1 - 10, Jun. 2018.

[6] D. Ambarwulan and D. Muliyati, "The Design of Augmented Reality Application as Learning Media Marker-Based for Android Smartphone", JPPPF (Jurnal Penelitian dan Pengembangan Pendidikan Fisika), vol. 2, no. 1, pp. 73 - 80, Jun. 2016.

[7] I. A. Putri, S. Siswoyo, and W. Indrasari, "Pengembangan Media Pembelajaran Fisika Menggunakan Lectora Inspire pada Materi Usaha dan Energi SMA", JPPPF (Jurnal Penelitian dan Pengembangan Pendidikan Fisika), vol. 2, no. 2, pp. 71 - 78, Dec. 2016.

[8] M. Fausih and T. Danang, "Pengembangan Media E-Modul Mata Pelajaran Produktif Pokok Bahasan ' Instalasi Jaringan Lan ( Local Area Network )' Untuk Siswa Kelas Xi Jurusan Teknik Komputer Jaringan Di SMK Nengeri 1 Labang," Bioedukasi, vol. 9, no. 20, pp. 1-9, 2015.

[9] K. W. B. Putra, I. M. A. Wirawan and G. A. Pradnyana, "Pengembangan e-Modul Berbasis Model Pembelajaran Discovery Learning Pada Mata Pelajaran 'Sistem Komputer' Untuk 
Siswa Kelas X Multimedia SMK Negeri 3 Singaraja," Jurnal Pendidikan Teknologi dan Kejuruan, vol. 14, no. 1, p. 10, 2017.

[10] F. Bakri, B. Z. Siahaan, and A. H. Permana, "Rancangan Website Pembelajaran Terintegrasi dengan Modul Digital Fisika Menggunakan 3D PageFlip Professional", JPPPF (Jurnal Penelitian dan Pengembangan Pendidikan Fisika), vol. 2, no. 2, pp. 113 - 118, Dec. 2016.

[11] F. Fitriyani, M. Muhaimin and M. Rusdi, "Pembelajaran Menggunakan Media 3D Pageflip Professional dan Media Camtasia Studio 8 pada Materi Larutan Elektrolit dan Non Elektrolit di Kelas X SMA Islam Al-Arief Muaro Jambi," Repository Universitas Of Jambi, vol. 2, no. 1, pp. 3-9, 2017.

[12] S. Warjanto, "Pengembangan Media Pembelajaran Induksi Elektromagnetik," Prosiding Seminar Nasional Fisika (E-Journal) SNF 2015, vol. IV, p. 4, 2015.

[13] I. Z. Ichsan et al., "HOTS-AEP: Higher Order Thinking Skills from Elementary to Master Students in Environmental Learning," European J Ed Res, vol. 8, no. 4, Oct. 2019, doi: 10.12973/eu-jer.8.4.935.

[14] G. M. Saido et al., "Higher Order Thinking Skills Among Secondary School Students in Science Learning," The Malaysian Online Journal of Educational Science, vol. 2, no. 3, p. 8, 2015.

[15] N. Nurhayati and L. Angraeni, "Analisis Kemampuan Berpikir Tingkat Tinggi Mahasiswa (Higher Order Thinking) dalam Menyelesaikan Soal Konsep Optika melalui Model Problem Based Learning”, JPPPF (Jurnal Penelitian dan Pengembangan Pendidikan Fisika), vol. 3, no. 2, pp. 119 - 126, Dec. 2017.

[16] M. G. Nugraha, K. H. Kirana, S. Utari, N. Kurniasih, N. Nurdini, and F. N. Sholihat, "Problem Solving-Based Experiment untuk Meningkatkan Keterampilan Penalaran Ilmiah Mahasiswa Fisika", jpppf, vol. 3, no. 2, pp. 137 - 144, Dec. 2017.

[17] W. Dick, L. Carey and J. O. Carey, "The Systematic Design of Instruction," 8th ed. United States of America: Pearson, 2015.

[18] Y. Mardiansyah, A. Asrizal and Y. Yulkifli, "Pembuatan Modul Fisika Berbasis TIK Untuk Mengintegrasikan Nilai Pendidikan Karakter Dalam Pembelajaran Siswa SMAN 10 Padang Kelas X Semester 1," Pillar of Physics Education, vol. 1, pp. 30-38, 2013.

[19] D. A. P. Sari, M. Hidayat and W. Kurniawan, "Pengembangan Modul Elektronik Fisika Berbasis Pendekatan Saintifik Materi Getaran Harmonis Menggunakan Kvisoft Flipbook Maker," Repository Universitas Of Jambi, vol. 1, no. 1, pp. 33-39, 2015.

[20] S. Mayanty, I. M. Astra and C. E. Rustana, "Pengembangan E-Modul Fisika Berbasis Problem Based Learning (PBL) Untuk Meningkatkan Keterampilan Proses Siswa SMA," Prosiding Seminar Nasional Quantum, vol. 25, pp. 1-13, 2018.

[21] I. Z. Ichsan et al., "HOTS-AEP-COVID-19: Students Knowledge and Digital Worksheet of ILMIZI Environmental Learning Model," International Journal of Advanced Science and Technology, vol. 29, no. 6, p. 12, 2020.

[22] I. Golitsyna, "Educational Process in Electronic Information-educational Environment," Procedia - Social and Behavioral Sciences, vol. 237, pp. 939-944, Feb. 2017, doi: 10.1016/j.sbspro.2017.02.132.

[23] H. Rahmayanti, I. Z. Ichsan and S. A. Azwar, "Indonesian Student Environmental Attitude of flood during COVID-19: DIFMOL Education Model in 21st Technology," International Journal of Advanced Science and Technology, vol. 29, no. 5, pp. 6245-6253, 2020. 
[24] H. Rahmayanti et al., "Environmental Attitude for Smart City Technology: Need Assessment to Develop Smart Trash in Environmental Education," International Journal of Advanced Science and Technology, vol. 29, no. 03, p. 11, 2020.

[25] I. Z. Ichsan et al., "Implementation Supplementary Book of Green Consumerism: Improving Students HOTS in Environmental Learning," European J Ed Res, vol. 9, no. 1, Jan. 2020, doi: 10.12973/eu-jer.9.1.227.

[26] A. Purwanto et al., "EM-SETS: An Integrated e-module of Environmental Education and Technology in Natural Science Learning," International Journal of Advanced Science and Technology, vol. 29, no. 03, p. 13, 2020.

[27] J. Reyna, J. Hanham and P. Meier, "The Internet explosion, digital media principles and implications to communicate effectively in the digital space," E-learning and Digital Media, vol. 15 , no. 1 , pp. 36-52, 2018. 